\title{
ROLA UBEZPIECZEŃ W KONCEPCJACH ZARZĄDZANIA RYZYKIEM WSPÓŁCZESNYCH PRZEDSIĘBIORSTW
}

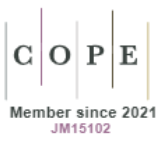

\author{
Teresa H. Bednarczyk ${ }^{*}$, Anna Szymańska** \\ THE ROLE OF INSURANCE IN THE RISK MANAGEMENT CONCEPTS OF \\ CONTEMPORARY ENTERPRISES
}

\begin{abstract}
The purpose of the article/hypothesis: Theoretical concepts to risk management in the enterprises evolve over time due to the rapid changes taking place both in the external and internal environment. The traditional approach to risk management gradually gives way to new concepts of the philosophy of holistic enterprise risk management. The aim of the study is to analyze these two concepts in terms of determining the current role and practical significance of the insurance method. The study verified the following research hypothesis: Despite the changing theoretical concepts of risk management, as well as the relative increase in the significance of uninsurable risk, in practice the insurance method still remains an important tool, especially in the risk management of large and medium-sized enterprises.

Methodology: The study is a theoretical and empirical in nature. The theoretical part was based on studies of domestic and foreign literature. The empirical part was based on a survey of the selected empirical studies and reports from advisory and consulting institutions, including the latest AON Polska 2019 report on risk management in enterprises

Results of the research: Most domestic enterprises implement a silo risk management model, and insurance as a method of financing the effects of risk materialization is still not losing its importance. Although the relative importance of insurance is decreasing due to the growing importance of uninsurable risk, such as the risk of economic and geopolitical instability, economic slowdown, increasing competition or lack of professional personnel, insurance has not lost its key role in practice, especially in large and medium-sized enterprises.
\end{abstract}

Keywords: risk management, insurance, enterprise.

JEL Class: G22, D81.

\footnotetext{
* Dr hab., prof. UMCS, Wydział Ekonomiczny, Uniwersytet Marii Curie-Skłodowskiej w Lublinie; https://orcid.org/0000-00029340-6864.

** Dr hab., prof. UŁ, Wydział Ekonomiczno-Socjologiczny, Uniwersytet Łódzki; https://orcid.org/0000-0003-4245-7802.
} 


\section{WSTĘP}

Współczesne przedsiębiorstwa narażone są na odmienne, ale często przenikające się rodzaje ryzyka. Ostatnie lata przyniosły wiele gwałtownych zmian w ich otoczeniu wewnętrznym i zewnętrznym. Postępujący proces globalizacji, rozwój zaawansowanych technologii, przemiany demograficzne, geopolityczne i klimatyczne sprawiają, że pojawiają się wciąż nowe, wcześniej nieznane zagrożenia. Wraz z początkiem XXI w. coraz groźniejsze stają się takie rodzaje ryzyka jak: ryzyko systemowe, ryzyko katastrof naturalnych, ryzyko energetyczne, ryzyko IT, ryzyko nasilających się ataków terrorystycznych, ryzyko pandemii czy ryzyko z obszaru kapitału ludzkiego, np. absencja oraz starzenie się i choroby pracowników, brak odpowiedniej kadry na rynku czy nieumiejętność przyciągania i zatrzymywania talentów.

Podejście naukowe i praktyczne do zarządzania ryzykiem także się zmienia. W nowoczesnych koncepcjach zarządzania ryzykiem, ubezpieczenia, które wcześniej były najważniejszym instrumentem finansowej kontroli ryzyka przestają pełnić rolę pierwszoplanową. Jednym z powodów tego stanu rzeczy jest brak, w ramach tradycyjnego paradygmatu, możliwości ubezpieczenia kluczowych dla przedsiębiorstw rodzajów ryzyka, takich jak: wzrastająca konkurencja, spowolnienie gospodarcze, wahania kursów walut czy zmiany w otoczeniu regulacyjnym (Bednarczyk, 2017). Nowoczesna koncepcja zintegrowanego podejścia do zarządzania ryzykiem w przedsiębiorstwie (ERM - Enterprise Risk Management) łączy zarządzanie ryzykiem z zarządzaniem całym przedsiębiorstwem oraz zarządzaniem ryzykiem poszczególnych linii biznesowych. Uwzględnia potrzebę ograniczania i kontroli finansowej również ryzyka nie przejmowanego obecnie przez ubezpieczycieli, czyli ryzyka finansowego, strategicznego i operacyjnego. Akcentowane są tutaj m.in. postulaty zapewniające bezpieczeństwo informacji i systemów informacyjnych, kwestie dotyczące ochrony reputacji oraz nowoczesne koncepcje planowania ciągłości działania i zarządzania ciągłością działania w biznesie.

Celem opracowania jest analiza dwóch koncepcji zarządzania ryzykiem w przedsiębiorstwie: koncepcji tradycyjnej, zwanej także silosową oraz koncepcji zintegrowanego (całościowego i wieloaspektowego) podejścia do zarządzania ryzykiem pod kątem ustalenia aktualnej roli i praktycznego znaczenia ubezpieczeń w tych koncepcjach. W opracowaniu zweryfikowano hipotezę badawczą w brzmieniu: Pomimo zmieniających się teoretycznych koncepcji zarządzania ryzykiem, a także relatywnego wzrostu znaczenia ryzyka nie nadającego się do ubezpieczenia, w praktyce biznesowej ubezpieczenia nadal zajmują ważne miejsce zwłaszcza w procesie zarządzania ryzykiem dużych i średnich przedsiębiorstw. 
Opracowanie ma charakter teoretyczno-analityczny. Obok przeglądu dostępnej literatury krajowej i zagranicznej, przeanalizowano również wyniki wybranych badań empirycznych oraz raportów instytucji doradczych i konsultingowych, w tym najnowszy raport AON Polska 2019 na temat zarządzania ryzykiem w przedsiębiorstwach.

\section{KONCEPCJE TEORETYCZNE ZARZĄDZANIA RYZYKIEM W PRZEDSIĘBIORSTWACH}

\subsection{Koncepcja tradycyjnego zarządzania ryzykiem}

Zarządzanie ryzykiem w aspekcie naukowym (metodologicznym) jak i praktycznym jest efektem zarówno rozwoju ekonomii i nauk o zarządzaniu, jak i wynikiem rozwoju sił wytwórczych w gospodarce, koncentracji produkcji i kapitału oraz rozwoju nowych technologii. Jest też odpowiedzią na różnego rodzaju wyzwania i zagrożenia, przed jakimi stają podmioty gospodarujące. Termin zarządzanie ryzykiem (Risk Management) nie posiada jak dotąd spójnego i jednolitego rozumienia, co wynika zarówno z jego interdyscyplinarnego charakteru jak i ciągłych dynamicznych zmian. Zarządzanie ryzykiem w najbardziej ogólnym znaczeniu oznacza ,szeroko rozumiane działania zarządcze, których zadaniem jest identyfikacja i ocena ryzyka i niepewności oraz walka z ich przyczynami i wpływem na organizację w celu umożliwienia jej rozwoju" (Williams i in. 2002). Według bardziej rozbudowanej definicji , zarządzanie ryzykiem to naukowe podejście do radzenia sobie z ryzykiem poprzez przewidywanie możliwych przypadkowych strat i projektowanie oraz implementację procedur, które minimalizują występowanie potencjalnych strat lub finansową siłę strat już powstałych" (Vaughan 1997).

W literaturze spotkać można dwa skrajne podejścia teoretyczne do zarządzania ryzykiem w przedsiębiorstwie: tradycyjne zarządzanie ryzykiem, zwane także silosowym (Silo Risk Management) oraz zintegrowane zarządzanie ryzykiem (Enterprise Risk Management - ERM). Tradycyjne zarządzanie ryzykiem polega na zajęciu aktywnej postawy wobec wybranych zagrożeń, uznanych za najważniejsze z punktu widzenia celów stawianych przed poszczególnymi działami przedsiębiorstwa (Kasiewicz, 2011). Ryzyko postrzegane jest tutaj jako zjawisko negatywne, przynoszące straty i/lub sprawiające, że faktycznie osiągnięte rezultaty, będą mniej korzystne niż zakładano. Przykładem silosowego podejścia do zarządzania ryzykiem jest: zarządzanie ryzykiem ubezpieczeniowym (IRM - Insurance Risk Management); zarządzanie ryzykiem finansowym (FRM - Financial Risk Management); zarządzanie ryzykiem strategicznym (SRM - Strategic Risk Management); zarządzanie ryzykiem projektów (PRM - Project Risk Management); zarządzanie ryzykiem łańcucha dostaw (ScRM - Supply Chain Risk Management ); zarządzanie ryzykiem inżynieryjnym (EnRM - Engineering Risk 
Management); zarządzanie ryzykiem katastrof - (DRM - Disaster Risk Management) (Verbano i Venturini 2013).

W podejściu tradycyjnym - ważną rolę odgrywa koncepcja zarządzania ryzykiem ubezpieczeniowym, która odwołuje się do klasyfikacji ryzyka zaproponowanego przez Mowbray`a. Wyróżnił on ryzyko czyste ${ }^{1}$ (pure risk, static risk) i ryzyko spekulatywne ${ }^{2}$ (speculative risk) (Mowbray i Blanchard 1961). Na gruncie teorii ubezpieczeń, zarządzanie ryzykiem ogranicza się do zarządzania jedynie ryzykiem czystym, czyli ekspozycją na ryzyko strat z wyłączeniem ryzyka spekulatywnego (Williams i in. 2002). Ubezpieczenia pozwalają finansować skutki urzeczywistnienia się ryzyka (zarządzać „szkodowością”), ponieważ świadczenie ubezpieczeniowe umożliwia odtworzenie utraconych zasobów (stanu sprzed szkody) i zachowanie ciągłości funkcjonowania przedsiębiorstwa. Ubezpieczenia postrzega się również w kategoriach istotnego stabilizatora przetrwania i rozwoju przedsiębiorstw (Jedynak 2009). Metoda ubezpieczeniowa była powszechnie wykorzystywana w XX wieku w USA i w krajach Europy Zachodniej. W większości dużych przedsiębiorstw zatrudniony był menedżer ubezpieczeń (insurance manager), odpowiedzialny za dobór i zakup ubezpieczeń.

Jednak metoda ubezpieczeniowa ma swoje ograniczenia, które wynikają zarówno z doktryny ubezpieczeń jak i z praktyki ubezpieczeniowej. W świetle paradygmatu ubezpieczalności ryzyka, przedstawionego przez Vaughana, ryzyko nadające się do ubezpieczenia (ubezpieczalne) musi spełniać łącznie cztery główne warunki (Vaughan i Vaughan, 2014; Kowalewski, 1997):

1. Duża liczba narażonych jednostek o charakterze homogenicznym, co warunkuje racjonalne przewidywanie ekonomicznych następstw strat.

2. Strata spowodowana przez zrealizowanie się danego ryzyka musi być definitywna (pozbawiona dowolności oceny) i mierzalna w znaczeniu finansowym, co oznacza, że zarówno fakt nastąpienia straty jak i jej rozmiar musi być względnie trudny do ,zafałszowania”.

3. Następstwo ryzyka musi mieć charakter nadzwyczajny lub przypadkowy, tzn., że na zrealizowanie się danego ryzyka nie może mieć wpływu żadna ze stron kontraktu, ani ubezpieczyciel, ani ubezpieczający (ubezpieczony).

4. Strata powstała w wyniku ryzyka nie może mieć charakteru katastrofalnego, tzn., że ryzyko nie może zrealizować się w stosunku do zbyt wielkiej liczby ,jednostek narażenia” w tym samym czasie.

Ważnym elementem paradygmatu ubezpieczalności ryzyka jest możliwość zastosowania prawa wielkich liczb, gdyż zgodnie z wymogami aktuarialnymi ryzyko nadające się do ubezpieczenia musi wykazywać się statystyczną powtarzalnością

${ }^{1}$ Ryzyko czyste może przynieść tylko dwa możliwe skutki: stratę (jeżeli się zrealizuje) lub brak straty (jeżeli się nie zrealizuje).

${ }^{2}$ Ryzyko spekulatywne - to niepewność wyniku działania, który może być zarówno stratą jak i szansą na zysk i osiągnięcie sukcesu rynkowego przedsiębiorstwa. 
w „dużej masie” przypadków, aby można było kwantyfikować go metodami statystycznymi. A zatem ryzyko nadające się do ubezpieczania to ryzyko wyselekcjonowane, które przy użyciu techniki ubezpieczeniowej, danych o częstości zdarzeń i średniej szkodowości jest wysoce przewidywalne (Hadyniak, 2010).

Jak wynika z paradygmatu ubezpieczalności, ryzyko spekulatywne, które nie jest kreowane przez czynniki losowe tylko przez czynniki ekonomiczne lub organizacyjne oraz ryzyko fundamentalne nie nadaje się do ubezpieczania z powodu ograniczonej zdolności branży ubezpieczeniowej do przejmowania jego skutków (Vaughan i Vaughan, 2014) W związku z tym w ramach tradycyjnej (rdzennej) działalności ubezpieczeniowej nie jest możliwe przeniesienie na ubezpieczyciela skutków finansowych wielu rodzajów ryzyka, zagrażającego współczesnym przedsiębiorstwom. Chodzi tu o takie rodzaje ryzyka jak: zmiany otoczenia instytucjonalnego, zmiany prawno-regulacyjne, spowolnienie gospodarcze, ograniczona dostępność do zasobów naturalnych, nasilająca się konkurencja, istotne zmiany popytu (utrata odbiorców), gwałtowne zmiany cen czynników produkcji, brak odpowiedniej kadry na rynku, niezdolność do przyciągania i zatrzymywania utalentowanych pracowników, niezdolność do opracowywania i wdrażania innowacji, brak odpowiedniej infrastruktury IT, zmienność stóp procentowych i kursów walutowych, ryzyko płynności, zagrożenia związane z outsourcingiem czy $\mathrm{z}$ przedsięwzięciami typu joint-venture. $\mathrm{Z}$ kolei straty wywołane przez ryzyko fundamentalne, takie jak: skutki ataków terrorystycznych, wojen i zamieszek, skutki wielkich katastrof naturalnych i technicznych nie powinny być obejmowane ubezpieczeniem $z$ uwagi na masowy charakter tych zdarzeń i kumulację szkód, z których roszczenia szkodowe mogłyby przekroczyć zdolność finansową ubezpieczycieli (Hadyniak, 2010).

Postęp technologiczny i obecne przemiany społeczno-gospodarcze kreują nowe zagrożenia tzw. emerging risks. Jako przykłady emerging risks wymienia się m.in.: ryzyko opóźnienia w łańcuchu dostaw, ryzyko potencjalnych strat z powodu wyczerpania się źródeł energii odnawialnej (np. wydajności paneli słonecznych), ryzyko kradzieży danych na nośnikach magnetycznych (tzw. cyber-ryzyka), ryzyko utraty reputacji przedsiębiorstw o uznanej marce, ryzyko strat z powodu zmian klimatycznych, czy ryzyko związane z nanotechnologią (Swiss Re, 2011). Te nowe zagrożenia charakteryzują się wysokim stopniem niepewności co do wystąpienia i jednocześnie dużym stopniem złożoności i współzależności oraz wysoką wartością potencjalnych strat. Zalicza się je do grupy ryzyka częściowo ubezpieczalnego, która nie wypełnia wszystkich cech modelu ubezpieczalności, jednak z uwagi na zapotrzebowanie ze strony rynku stopniowo staje się przedmiotem ubezpieczeń (Raport Aon Polska, 2019). Obecnie mamy do czynienia z nowym ryzykiem związanym z pandemią Covid-19, która uruchomiła wiele negatywnych procesów, mogących stanowić wyzwanie także dla rynku ubezpieczeniowego w Polsce (Lisowski, 2021). 


\subsection{Koncepcja zintegrowanego zarządzania ryzykiem}

W opozycji do tradycyjnego, finansowo-ubezpieczeniowego postrzegania problematyki ryzyka stoi koncepcja zintegrowanego zarządzania ryzykiem (ERM). Jest to nowoczesna koncepcja (nowy paradygmat), która obejmuje zespół metod i technik identyfikacji, opisu, pomiaru, analizy i oceny ryzyka oraz przyjętych mechanizmów działania (strategia, reagowanie i monitoring), ukierunkowanych na realizację celów przedsiębiorstwa w kontekście tworzenia i ochrony wartości dla jego interesariuszy (Wróblewski, 2011). Koncepcja zintegrowanego zarządzania ryzykiem opiera się na uniwersalnym i holistycznym podejściu do zarządzania ryzykiem korporacyjnym. Zarządzanie ryzykiem jest tutaj zintegrowane z zarządzaniem całym przedsiębiorstwem i odnosi się do zarządzania wszystkimi typami i rodzajami ryzyka identyfikowanego w przedsiębiorstwie.

Proces zintegrowanego zarządzanie ryzykiem wymaga stworzenia w przedsiębiorstwie określonych struktur organizacyjnych, takich jak: komitet do spraw ryzyka; osobne departamenty zarządzania ryzykiem i ubezpieczeń, podległe dyrektorowi finansowemu, zarządowi lub dyrektorowi generalnemu; ustanowienie funkcji risk managera oraz struktury i składu zespołu zarządzania ryzykiem. Podstawowym obowiązkiem specjalistów i menedżerów ryzyka powinno być wykonywanie zadań z zakresu kontroli ryzyka (bezpieczeństwa) oraz aranżacja i administrowanie programami ubezpieczeń. W mniejszych przedsiębiorstwach odpowiedzialność za zarządzanie ryzykiem może być w gestii dyrektora finansowego, prezesa firmy lub komórki audytu wewnętrznego.

Koncepcja zintegrowanego zarządzania ryzykiem (ERM) powstała głównie w toku praktyk menadżerskich, z udziałem przedstawicieli firm doradczych i konsultingowych. Nie jest ona całkowicie jednolita, ponieważ ma swoje korzenie w kilku międzynarodowych standardach dotyczących postępowania organizacji w warunkach ryzyka. Najpopularniejsze standardy to: FERMA, COSO II, AS/ZZS 4360, ISO 31000:2009. Standardy te umożliwiają wprowadzanie rozwiązań mających na celu zwiększenie poziomu bezpieczeństwa funkcjonowania przedsiębiorstw o różnej wielkości, które poszukują kompleksowego, a zarazem elastycznego systemu zarządzania ryzykiem z możliwością jego modyfikacji i indywidualizacji. Przykładowo, zgodnie z najbardziej popularnym międzynarodowym standardem FERMA: 2002, zarządzanie ryzykiem stanowi centralny element zarządzania strategicznego i operacyjnego w organizacji. Jest procesem, w ramach którego organizacja w sposób metodyczny rozwiązuje problemy wynikające z urzeczywistnienia się ryzyka, w taki sposób, aby ta działalność przynosiła trwałe korzyści, takie jak: zwiększanie wartości dla akcjonariuszy i przyczynianie się do realizacji innych celów organizacji (FERMA, 2003).

W nowoczesnej koncepcji zintegrowanego zarządzania ryzykiem ubezpieczenie straciło priorytetowe znaczenie, ponieważ ryzyko traktowane jest nie tylko 
jako zagrożenie (aspekt negatywny), ale i szansa na osiągnięcie dodatkowych korzyści (aspekt pozytywny). W koncepcji ERM zarządzać należy także tymi rodzajami ryzyka, które wynikają z decyzji i działań biznesowych, a które nie mają charakteru losowego i których nie da się ubezpieczyć, ani dostatecznie dobrze rozproszyć. Istotą koncepcji zintegrowanego zarządzania ryzykiem jest rozpatrywanie różnych jego rodzajów przy uwzględnieniu występujących między nimi współzależności. Zarządza się całym portfelem ryzyka przez pryzmat celów i procesów całej organizacji (Monkiewicz i Gąsiorkiewicz, 2010). W związku z tym w nowoczesnych koncepcjach zarządzania ryzykiem mówi się nie tyle o minimalizowaniu, co o optymalizowaniu ryzyka. Optymalizacja ryzyka rozumiana jest jako „podejmowanie decyzji i realizacja działań prowadzących do osiągnięcia akceptowalnego poziomu ryzyka" (Jajuga, 2007).

Idea zintegrowanego zarządzania ryzykiem w przedsiębiorstwie uwzględnia kwestie ochrony nie tylko zasobów materialnych i finansowych - co jest typowe w koncepcji tradycyjnej - ale także zasobów niematerialnych, takich jak: kapitał marki czy kapitał intelektualny. Szacuje się, że współcześnie ok. 80\% wartości rynkowej przedsiębiorstwa jest generowane $\mathrm{z}$ aktywów niematerialnych (intangables). Nic dziwnego, że przedsiębiorstwa o ugruntowanej pozycji na rynku i uznanej marce przywiązują dużą wagę do właściwego zarządzania ryzykiem reputacji (Kasiewicz, 2011).

Po wybuchu globalnego kryzysu finansowego, większą uwagę zaczęto zwracać na ryzyko systemowe. Chodzi o zdarzenia o bardzo małym wręcz minimalnym prawdopodobieństwie zaistnienia („Black Swan”), ale o ogromnych negatywnych skutkach. Skuteczne przewidywanie tego typu zdarzeń z perspektywy pojedynczych przedsiębiorstw jest niezwykle trudne, wręcz niemożliwe. Przedsiębiorstwa mogą jedynie budować swoją odporność na negatywne konsekwencje zdarzeń kryzysowych o charakterze systemowym (Taleb, 2007).

Pandemia Covid-19 w 2020 roku wywołała szok dla światowej gospodarki, który jest zgoła inny niż w przypadku globalnego kryzysu finansowego. W latach 2007-2009 problemem był kryzys bankowy, który po pewnym czasie rozprzestrzenił się na całą sferę finansową gospodarki, a potem także i na sferę realną gospodarki oraz finanse publiczne. Pandemia COVID 19 spowodowała nagły szok w całej gospodarce światowej w bardzo krótkim czasie. Jest uznawana jednocześnie za katastrofę naturalną i kryzys finansowy, którego negatywny i długotrwały wpływ odczują także przedsiębiorstwa (Prime i in., 2020). W innych publikacjach pandemię COVID-19 uznaje się jako szczególny przypadek ryzyka systemowego (Solarz i Waliszewski, 2020).

Idea zintegrowanego zarządzania ryzykiem obejmuje również nowoczesne koncepcje zapewnienie ciągłości działania, takie jak: koncepcja planowania ciągłości działania - BCP - business continuity planning; zarządzanie ciągłością działania - business continuity management - BCM; Plany awaryjne IT (Disaster 
Recovery Plans - DRP) ${ }^{3}$. W koncepcji ERM ryzyko ubezpieczeniowe jest tylko jednym $\mathrm{z}$ wielu rodzajów ryzyka zagrażającego organizacji ${ }^{4}$. W standardzie zarządzania ryzykiem FERMA wyróżniono cztery główne rodzaje ryzyka: ryzyko finansowe, strategiczne, operacyjne i niebezpieczeństwa zwane również ryzykiem naturalnym (materialnym) (FERMA, 2003). W kontekście zintegrowanego zarządzania ryzykiem, ryzyko ubezpieczeniowe stanowi niewielki odsetek całości ryzyka zagrażającego przedsiębiorstwom, podczas gdy ryzyko nieubezpieczalne stanowi zdecydowaną większość (Wadé, 2014). Są też i takie głosy, że w turbulentnym otoczeniu przedsiębiorstwa $\mathrm{w}$ globalnej gospodarce, przy rosnącej zmienności otoczenia i pod presją zmian wynikających z synergii zmian technologicznych, rośnie znaczenie ubezpieczeń w zarządzaniu ryzykiem, zwłaszcza ryzykiem regulacyjnym i ryzykiem technologicznym (Wierzbicka, 2017).

W ostatnim czasie trwa dyskusja naukowa na temat potrzeby modyfikacji obowiązującego paradygmatu tzw. ekonomii głównego nurtu oraz rozumienia i postulatów nauk ekonomicznych wobec praktyki zarządzania biznesem. Chodzi w szczególności o ewaluację sprawności pracy top managementu. Przesądza o tym splotu czynników, które pandemia COVID-19 jeszcze bardziej spotęgowała (Banaszyk i in., 2021).

\section{ZARZAADZANIE RYZYKIEM W PRZEDSIĘBIORSTWACH W ŚWIETLE PRZEGLĄDU WYBRANYCH BADAŃ EMPIRYCZNYCH}

\subsection{WDRAŻANIE KONCEPCJI ERM NA ŚWIECIE}

W praktyce koncepcje zarządzania ryzykiem w przedsiębiorstwach mają charakter zróżnicowany, uzależniony od poziomu rozwoju gospodarczego kraju, rodzaju prowadzonej działalności, branży czy wielkości przedsiębiorstwa. Przedsiębiorstwa stosują różne podejścia do zarządzania ryzykiem. Koncepcja ERM najczęściej znajduje zastosowanie w branży finansowej. Instytucje finansowe (ubezpieczyciele, banki, fundusze inwestycyjne) są zachęcane przez organy regulacyjne do wdrożenia ERM. W 2014 roku 92\% respondentów reprezentujących średnie i duże instytucje finansowe działające w skali globalnej stwierdziło, że koncepcja ERM jest już wdrożona lub jest w trakcie wdrażania (Hida, 2015).

W przedsiębiorstwach niefinansowych koncepcja zintegrowanego zarządzania ryzykiem nie jest jeszcze powszechnie realizowana, pomimo że istnieją liczne 2010].

${ }^{3}$ Szerzej na ten temat zob. m.in: (Kaszuba-Perz i Perz, 2010; Monkiewicz i Gąsiorkiewicz,

${ }^{4}$ Firma doradcza Ernst \& Yung, w jednym ze swoich raportów badawczych, który dotyczył typologii obszarów ryzyka we współczesnych przedsiębiorstwach w ogóle nie wyróżniła ryzyka ubezpieczeniowego, a jedynie wymieniła niektóre jego rodzaje w grupie ryzyka operacyjnego, por.: (Ernst \& Yung, 2009). 
przesłanki do jej wprowadzenia, wynikające m.in. z zasad ładu korporacyjnego (corporate governance). Także niektóre agencje ratingowych $\mathrm{np}$. Standard \& Poor's wymagają posiadania systemu zarządzania ryzykiem jako czynnika niezbędnego do oceny kondycji przedsiębiorstwa (Szewczuk, 2012). Badania empiryczne przeprowadzone w 2008 roku na próbie 700 amerykańskich przedsiębiorstw pokazały, że tylko $9 \% \mathrm{z}$ nich posiada wdrożony całościowy system ERM. Kolejnych $22 \%$ stwierdziło, iż wdrożyło częściowo powyższy system. Natomiast ponad $60 \%$ respondentów przyznało, że formalny system kompleksowego zarządzania ryzykiem nie został jeszcze wdrożony (Beasley i in., 2009). Z kolei na podstawie badania przeprowadzonego przez College of Management at North Carolina State we współpracy z Committee of Sponsoring Organizations of the Treadway Commission (COSO) w czerwcu i lipcu 2010 roku, w którym wzięło udział 460 podmiotów, można stwierdzić, że tylko $20 \%$ respondentów oceniło poziom zaawansowania zarządzania ryzykiem w swojej firmie jako dojrzały. Natomiast $42,4 \%$ respondentów określiło procesy zachodzące w swoich organizacjach jako „niedojrzałe” (lub „mało dojrzałe”) w działaniach dotyczących kontroli ryzyka. Inne międzynarodowe badanie ankietowe przeprowadzone na próbie ponad 1500 przedsiębiorstw europejskich wykazało, że aż połowa badanych nie posiada strategii zarządzania ryzykiem, a tylko $43 \%$ z nich wyznacza mierzalne cele w zakresie nadzorowania ryzyka (Zdunek, 2017). Jako bariery we wdrażaniu kompleksowego systemu zarządzania ryzykiem wskazano m.in.: istnienie innych konkurencyjnych priorytetów, brak wystarczających zasobów finansowych i kadrowych do wdrożenia ERM, brak przeświadczenia o uzyskania wymiernych korzyści z wdrożenia tego typu sytemu, brak wystarczającego wsparcia ze strony zarządu w procesie implementacji ERM, jak również przekonanie, że wdrożenie ERM przyczyni się do wzrostu biurokracji w organizacji (Beasley i in., 2009).

\subsection{WDRAŻANIE KONCEPCJI ERM W POLSKICH PRZEDSIĘBIORSTWACH}

W przedsiębiorstwach działających w Polsce, koncepcja ERM jest jeszcze mniej znana. O niskim poziomie wdrożenia $\mathrm{w}$ przedsiębiorstwach zintegrowanego (kompleksowego) zarządzaniem ryzykiem świadczą wyniki wielu badań empirycznych. Przykładowo w świetle badań empirycznych przeprowadzonych w 2015 r. tylko 45\% spółek giełdowych deklarowało wdrożenie systemów ERM, przy czym w przypadku części spółek giełdowych deklarujących stosowanie ERM, opisywane systemy nie spełniały większości podstawowych założeń koncepcji zintegrowanego zarządzania ryzykiem. Pozostałe 55\% badanych prezentowało postawę wobec ryzyka, charakterystyczną dla tradycyjnego, silosowego podejścia do zarządzania ryzykiem w organizacji (Przetacznik, 2017). 
Z kolei 71\% badanych małych i średnich przedsiębiorstw funkcjonujących na terenie województwa śląskiego przyznało, że nie wdrożyło żadnego systemu zarządzania ryzykiem (Gaschi-Uciecha, 2016). Podobnie wynika z innych ogólnopolskich badań ankietowych, przeprowadzonych w okresie od października 2015 roku do stycznia 2016 roku, na próbie 244 przedsiębiorstw różnej wielkości. Jedynie 11\% respondentów zadeklarowało wdrożenie systemu zarządzania ryzykiem w przedsiębiorstwie (niecałe 4\% podmiotów małych, ponad 19\% podmiotów średnich i prawie 33\% dużych firm), przy czym w pogłębionym badaniu stwierdzono, że zaledwie $6 \%$ z nich faktycznie wykonuje wszystkie działania, które powinny być wykonywane w ramach procesu zarządzania ryzykiem w przedsiębiorstwie. Znaczny odsetek badanych, chociaż deklaruje, że zarządza ryzykiem, jednak czyni to w sposób wybiórczy, ograniczony, stosując jedynie część czynności standardowego procesu zarządzania ryzykiem. Aż 75\% respondentów odpowiedziało, że nie ma wdrożonego żadnego systemu, a 14\% ankietowanych nie potrafiło odpowiedzieć, czy w przedsiębiorstwie taki system został wdrożony czy też nie (Sobolewski i Marcinkowski, 2017). A zatem z analizy szeregu badań empirycznych wynika, że większość polskich spółek zarządza tylko niektórymi rodzajami ryzyka, ignorując przy tym pozostałe zagrożenia związane z prowadzoną działalnością (Kasiewicz i in., 2011; Kasiewicz 2011).

Nieco optymizmu dostarcza najnowszy raport firmy konsultingowo-doradczej AON Polska 2019/2020, która prowadzi od 2009 r. cykliczne badania na temat zarządzania ryzykiem i ubezpieczeniami na próbie ponad 160 przedsiębiorstw z różnych branż i różnej wielkości. Wynika z niego, że świadomość menadżerów badanych przedsiębiorstw, dotycząca zarządzania ryzykiem powoli rośnie. Świadczy o tym odsetek firm w Polsce, które przyznały, że opracowały politykę zarządzania ryzykiem. Są to zwykle duże korporacje. Natomiast niemal co trzeci respondent przyznaje, że nie dokonuje pomiaru efektywności zarządzania ryzykiem (Raport AON Polska, 2019). Z najnowszego raportu AON wynika również, że rośnie odsetek firm w Polsce, które posiadają departament lub zespół zarządzania ryzykiem i ubezpieczeniami. W porównaniu z wynikami sprzed dwóch lat odsetek ten wzrósł niemal trzykrotnie, co jest zjawiskiem pozytywnym.

Jak wskazują badania firmy AON Polska przeprowadzone w latach 20192020 badane przedsiębiorstwa najbardziej obawiają się ryzyka finansowego, związanego z bieżącymi problemami z płatnościami od kontrahentów, ryzyka płynności, ryzyka walutowego i kredytowego, a także wpływu czynników zewnętrznych, takich jak spowolnienie gospodarcze, tempo zmian czynników rynkowych i geopolitycznych oraz wzrost konkurencji. Rodzajami ryzyka, którego znaczenie w Polsce wzrosło w porównaniu z poprzednimi latami, jest tempo zmian czynników rynkowych i geopolitycznych oraz ryzyka dotyczącego kapitału ludzkiego w postaci braku odpowiedniej kadry na rynku oraz absencji pracowników i menadżerów (por. tab. 1). 
Tabela 1. Kluczowe ryzyka oraz przygotowanie przedsiębiorstw na ich wystąpienie w postaci formalnych planów działania, w świetle VI edycji badania AON Polska

\begin{tabular}{|c|c|c|c|c|}
\hline \multicolumn{3}{|c|}{ Ranking 2019/2020 } & \multicolumn{2}{|l|}{ Ranking 2019/2020 } \\
\hline Kluczowe ryzyka & $\begin{array}{c}\text { Zmiana } \\
\text { miejsca } \\
\text { względem } \\
\text { rankingu } \\
\text { z 2017/18 }\end{array}$ & $\begin{array}{l}\text { Rodzaj } \\
\text { ryzyka }\end{array}$ & $\begin{array}{l}\text { Posiadanie formalnych planów } \\
\text { działania }\end{array}$ & \% wskazań \\
\hline Ceny towarów & +3 & $\mathrm{~N}$ & $\begin{array}{l}\text { Odpowiedzialność cywilna } \\
\text { (w tym zawodowa) }\end{array}$ & 73 \\
\hline $\begin{array}{l}\text { Należności } \\
\text { handlowe/płatności } \\
\text { kontrahentów }\end{array}$ & +2 & $\mathrm{U}$ & $\begin{array}{l}\text { Należności handlowe/płatności } \\
\text { kontrahentów }\end{array}$ & 72 \\
\hline $\begin{array}{l}\text { Spowolnienie } \\
\text { gospodarcze }\end{array}$ & - & $\mathrm{N}$ & $\begin{array}{l}\text { Awaria systemów } \\
\text { informatycznych }\end{array}$ & 67 \\
\hline $\begin{array}{l}\text { Cashflow/ryzyko } \\
\text { płynności }\end{array}$ & +3 & $\mathrm{CzU}$ & $\begin{array}{l}\text { Kradzież/przestępczość } \\
\text { pracownicza }\end{array}$ & 67 \\
\hline $\begin{array}{l}\text { Tempo zmian czynni- } \\
\text { ków rynkowych } \\
\text { i geopolitycznych }\end{array}$ & +26 & $\mathrm{~N}$ & Sprzeniewierzenie & 67 \\
\hline $\begin{array}{l}\text { Wzrastająca } \\
\text { konkurencja }\end{array}$ & -5 & $\mathrm{~N}$ & $\begin{array}{l}\text { Nieaktualna infrastruktura } \\
\text { techniczna }\end{array}$ & 67 \\
\hline $\begin{array}{l}\text { Brak odpowiedniej } \\
\text { kadry na rynku }\end{array}$ & +1 & $\mathrm{~N}$ & Cashflow/ryzyko płynności & 65 \\
\hline Absencja & +19 & $\mathrm{~N}$ & Zmienność stóp procentowych & 65 \\
\hline $\begin{array}{l}\text { Wahania kursów } \\
\text { walut }\end{array}$ & -3 & $\mathrm{~N}$ & $\begin{array}{l}\text { Dostępność kapitału ryzyko } \\
\text { kredytowe }\end{array}$ & 63 \\
\hline $\begin{array}{l}\text { Dostępność kapitału } \\
\text { ryzyko kredytowe }\end{array}$ & +3 & $\mathrm{~N}$ & $\begin{array}{l}\text { Wymagania RODO/brak } \\
\text { zgodności }\end{array}$ & 56 \\
\hline
\end{tabular}
czalne

$\mathrm{U}$ - ryzyko ubezpieczalne, $\mathrm{N}$ - ryzyko nieubezpieczalne, CzU - ryzyko częściowo ubezpie-

Źródło: opracowanie własne na podstawie: Raport AON Polska, 2019.

Przygotowanie przedsiębiorstw na wystąpienie kluczowych rodzajów ryzyka w postaci formalnych planów działania jest mocno zróżnicowane (por. tab. 1). Badane przedsiębiorstwa są najlepiej przygotowane do zagrożenia związanego z odpowiedzialnością cywilną oraz należnościami handlowymi i płatnościami kontrahentów (72\% respondentów przyznało, iż takie plany posiada). Stosunkowo 
dobrze są przygotowane badane przedsiębiorstwa na ryzyko techniczne (awaria systemów informatycznych, Kradzież/przestępczość pracownicza, sprzeniewierzenie, nieaktualna infrastruktura techniczna), które może być przedmiotem ubezpieczeń oraz na ryzyko natury finansowej (ryzyko należności handlowych, ryzyko płynności, ryzyko zmienności stóp procentowych i ryzyko walutowe), które może być zarządzane za pomocą znanych od dawna instrumentów pochodnych i innych i innych instrumentów finansowych (factoring). Natomiast niski stopień przygotowania na ryzyko zmienności cen towarów oraz na ryzyko o charakterze strategicznym (wzrastająca konkurencja i spowolnienie gospodarcze) wynika prawdopodobnie ze skomplikowanego charakteru tego rodzaju ryzyka, jego wieloaspektowości oraz trudności w pomiarze, a także braku możliwości ubezpieczania go. Zdecydowanie najniższy odsetek firm posiada plan działania dla ryzyka dotyczącego spowolnienia gospodarczego (14\%). Nieco polepszył się poziom przygotowania przedsiębiorstw na brak odpowiedniej kadry na rynku pracy (wzrost odsetka przygotowanych firm z 30\% do 43\%). Na ryzyko absencji formalny plan działania posiada 44\% firm. Należy odnotować również to, że więcej niż połowa przedsiębiorstw nie posiada formalnego planu działania w przypadku aż sześciu z dziesięciu kluczowych rodzajów ryzyka (Raport AON Polska, 2019).

Z przeprowadzonych analiz raportów i badań empirycznych można wywnioskować, że model ERM realizowany jest jedynie przez część dużych korporacji. Natomiast w większości krajowych przedsiębiorstw, zwłaszcza małych i średnich, realizowany jest nadal tradycyjny (silosowy) model zarządzania ryzykiem, koncentrujący się głównie na ochronie zasobów materialnych i finansowych przedsiębiorstwa w ramach metody ubezpieczeniowej. Zarządzanie ryzykiem ubezpieczeniowym w średnich i dużych przedsiębiorstwach polega na podejmowaniu świadomych decyzji dotyczących proporcji między wyborem optymalnego portfela ubezpieczeń, a poziomem zatrzymania ryzyka na udziale własnym (Strupczewski i Thlon, 2014). W świetle badań empirycznych przeprowadzonych przez Strupczewskiego i Thlona, głównym czynnikiem (52\% wskazań) decydującym o zakupie ubezpieczeń są wymogi przypisów prawa lub kontrahentów (w szczególności banków, firm leasingowych, zleceniodawców). 53\% respondentów przyznało, iż retencja ryzyka wymaga utrzymywania płynnych rezerw finansowych na wypadek wystąpienia szkód losowych, a to wiąże się z ponoszeniem kosztów alternatywnych kapitału. Zdaniem 26\% ankietowanych, ubezpieczenie zapewnia skuteczniejszą ochronę w razie wystąpienia klęski żywiołowej niż retencja oraz generalnie - jest lepszym gwarantem zachowania płynności finansowej w firmie po wystąpieniu zdarzenia szkodowego. $25 \%$ ankietowanych uważa, że posiadanie ubezpieczenia zwiększa wiarygodność firmy w oczach partnerów biznesowych. Tylko 4\% respondentów doceniło korzyści „dodatkowe” związane z zawarciem umowy ubezpieczenia, takie jak: identyfikacja i wycena ryzyka, administrowanie funduszem ubezpieczeniowym, prowadzenie likwidacji szkody, ustalenie 
okoliczności wypadku ubezpieczeniowego (często z udziałem rzeczoznawców), wycena szkody, pomoc prawna, dochodzenie roszczeń regresowych, itp.

Poziom dojrzałości zarządzania ryzykiem w przedsiębiorstwach mikro i małych jest jeszcze niższy. Badania przeprowadzone w podkarpackim klubie biznesowym na grupie 139 przedsiębiorstw wskazują, że w zdecydowanej większości mikro i małych przedsiębiorstw proces zarządzania ryzykiem w praktyce nie funkcjonuje (Dankiewicz i Ostrowska-Dankiewicz, 2014). Problem polega na tym, że przedsiębiorstwa z sektora MŚP często nie są świadome zagrażającego im ryzyka. Nie posiadają w strukturach organizacyjnych specjalnych komórek zajmujących się zarządzaniem ryzykiem, nie mają też sformalizowanych procedur (Gajda, 2014).

Wyniki badań empirycznych pokazują jednoznacznie, że pomimo stale rozszerzającej się oferty ubezpieczeniowej przedsiębiorstwa z sektora MSP stosunkowo rzadko korzystają z ubezpieczeń (Bera, 2005; Borda i Kwiecień, 2007). Najczęściej stosowanymi metodami identyfikacji i oceny ryzyka oraz decyzji o zakupie ochrony ubezpieczeniowej jest dotychczasowe doświadczeni i intuicja właścicieli lub menedżerów. Wiedza i kwalifikacje kadry zarządzającej często nie są wystarczające, aby efektywnie zarządzać ryzykiem. Mikro i małe przedsiębiorstwa niezwykle rzadko korzystają z usług brokerów (Gajda, 2014). Ponadto małe i średnie przedsiębiorstwa dokonują istotnych cięć w wydatkach na ubezpieczenia ograniczając się niejednokrotnie do zakupu jedynie ubezpieczeń obowiązkowych i tych wymuszonych zawartymi umowami, np. kredytowymi (Mikulska, 2010).

Najgorzej sytuacja przedstawia się wśród mikroprzedsiębiorstw. W 2013 roku co czwarte mikroprzedsiębiorstwo nie korzystało z żadnej formy ochrony ubezpieczeniowej (Wierzbicka, 2014). Jest to sytuacja o tyle niepokojąca, że małe i mikro firmy to podmioty $\mathrm{w}$ dużym stopniu narażone na zdarzenia związane z niewywiązaniem się przez ich kontrahentów z podjętych zobowiązań (ryzyka finansowe), a także na szybkie ,wypadnięcie” z rynku w sytuacji zniszczenia mienia stanowiącego zaplecze produkcyjne w wypadku zajścia zdarzenia losowego. Niestety barierą korzystania z ubezpieczeń dla tych podmiotów nadal jest bardzo niska świadomość ubezpieczeniowa.

\section{PODSUMOWANIE}

Ubezpieczenia jako rodzaj narzędzia finansowej kompensacji strat losowych w działalności gospodarczej mają dość długą historię. W tradycyjnym modelu zarządzania ryzykiem stanowią powszechnie stosowane instrumenty transferu i finansowania ryzyka. Są też uznawane za optymalną metodę i synonim tradycyjnego (silosowego) procesu zarządzania ryzykiem w przedsiębiorstwach. W świetle nowoczesnej koncepcji ERM - ubezpieczenie utraciło priorytetowe znaczenie 
i jest jednym z instrumentów „reakcji na ryzyko”, wkomponowanych w zorganizowany proces kompleksowego zarządzania ryzykiem, tak aby jego wykorzystanie było jak najbardziej efektywne i skuteczne.

Jak wynika z wielu badań empirycznych, proces zarządzania ryzykiem w krajowych przedsiębiorstwach jest nadal mało sformalizowany, co świadczy o bardzo powolnej implementacji koncepcji ERM. Ogromne braki dotyczą zwłaszcza tworzenia struktur organizacyjnych (komitetów do spraw ryzyka, departamentów lub zespołów zarzadzania ryzykiem), kwestii zarządzania sytuacjami kryzysowymi i planów ciągłości działania. Nadal w przedsiębiorstwach dominuje jednostronne postrzeganie ryzyka, zarządzanie tylko niektórymi jego rodzajami oraz ignorowanie holistycznego podejścia do zarządzania ryzykiem i uwzględniania współzależności między różnymi jego rodzajami. Decydenci koncentrują się raczej na minimalizowaniu dodatkowych kosztów zarządzania ryzykiem niż na ogólnej koncepcji wzrostu wartości dla akcjonariuszy.

Na podstawie przeglądu wybranych badań empirycznych można stwierdzić, że w większości krajowych przedsiębiorstw realizowany jest silosowy model zarządzania ryzykiem, a ubezpieczenie jako metoda finansowania skutków urzeczywistnienia się ryzyka wciąż nie traci na znaczeniu. Chociaż względne znaczenie ubezpieczeń maleje z powodu wzrostu znaczenia ryzyka nie nadającego się do ubezpieczenia (takiego jak np. ryzyko niestabilności ekonomicznej i geopolitycznej, spowolnienia gospodarczego, wzrastającej konkurencji, czy braku profesjonalnych kadr), to jednak ubezpieczenia nie utraciły kluczowej roli w praktyce, zwłaszcza dużych i średnich przedsiębiorstw. Menedżerowie stają się coraz bardziej świadomi zarówno zalet, jak i ograniczeń związanych z metodą ubezpieczeniową, lepiej rozumieją też znaczenie zapisów ogólnych warunków ubezpieczeń. Oczekują od ubezpieczycieli przede wszystkim atrakcyjnych składek, większej elastyczności i szerszego zakresu ochrony oraz sprawnej likwidacji szkód. Wskazują też na potrzebę bardziej zindywidualizowanego podejścia do underwritingu. Swego rodzaju szansą dla lepszego zaspakajania potrzeb ubezpieczeniowych klientów korporacyjnych jest gwałtowny skok technologiczny, który obserwujemy w okresie pandemii Covid 19. Sektor ubezpieczeniowy był często postrzegany jako dość konserwatywny jeśli chodzi o gotowość do wdrażania innowacyjnych rozwiązań. Sytuacja ta zaczęła się obecnie diametralnie zmieniać. Zarysowane już przed pandemią pewne trendy w zakresie automatyzacji czy szeroko rozumianych zmian technologicznych, ulegają gwałtownemu przyspieszeniu. Lockdown, wymuszający przejście na pracę zdalną, niewątpliwie je jeszcze umocnił. Zdalne formy pracy, sprzedaży, oględzin, likwidacji szkód itp. upowszechniły się. $\mathrm{Na}$ tej podstawie można żywić nadzieję, że ów sukces w transformacji technologicznej będzie kontynuowany. 
Nieco inaczej wygląda sytuacja w mikro i małych przedsiębiorstwach. Tutaj ubezpieczenia pozostają podstawowym, a czasem jedynym narzędziem ograniczania ryzyka. Niestety, w sektorze mikroprzedsiębiorstw ubezpieczenia są wykorzystywane w minimalnym zakresie. Wynika stąd wniosek, że stan zarządzania ryzykiem $\mathrm{w}$ tych przedsiębiorstwach nadal pozostaje na niezadawalającym poziomie.

Reasumując należy stwierdzić, że większość przedsiębiorstw działających w Polsce nie przykłada należytej wagi do problemu zarządzania ryzykiem w ogóle, co wynikać może po części z braków wiedzy na temat dostępnych na rynku instrumentów finansowych ograniczania ryzyka oraz metod zarządzania nim. Jedną $\mathrm{z}$ ważnych barier powolnego wdrażania koncepcji ERM jest niska świadomość menedżerów oraz tzw. uśpiony rynek konsultingowo-doradczy. Przedsiębiorstwa nie zgłaszają zbyt dużego popytu na tego typu usługi, w związku z czym aktywność firm doradczych i konsultingowych jest dość umiarkowana. Podkreślić należy również fakt, że niewiele wyższych uczelni ekonomicznych kształci profesjonalnych menedżerów ryzyka - zarówno na studiach magisterskich, jak i podyplomowych.

W 2020 roku przedsiębiorstwa w Polsce i na świecie na różne sposoby zostały dotknięte przez zakłócenia związane z pandemią Covid 19. Wiele z nich boryka się z problemami finansowymi i trudnościami w regulowaniu swoich zobowiązań. Pomimo bezprecedensowych wysiłków rządów w celu powstrzymania i złagodzenia skutków pandemii COVID 19, i tak doszło do gwałtownego spadku popytu na pracę $\mathrm{w}$ wielu sektorach gospodarki i spowodowało początkowo poważne niedobory siły roboczej $w$ innych sektorach. Ujawniły się również znaczące słabości w operacjach biznesowych i łańcuchach dostaw. Menedżerowie przedsiębiorstw stanęli przed wieloma nieoczekiwanymi dylematami i byli zmuszeni do podejmowania wielu niestandardowych decyzji.

\section{BIBLIOGRAFIA}

Banaszyk, P.,Deszczyński, P., Gorynia, M., Malaga, K. (2021). Przesłanki modyfikacji wybranych koncepcji ekonomicznych na skutek pandemii COVID-19. Gospodarka Narodowa, 1(305).

Beasley, M.S., Branson, B.C., Hancock, B.V. (2009). ERM: Opportunities for Improvement. Journal of Accountancy, 208.

Bednarczyk, T.H. (2017). Miejsce i rola ubezpieczeń w strategiach zarządzania ryzykiem przedsiębiorstw. W: R. Dankiewicz, A. Ostrowska-Dankiewicz, red., Ubezpieczenia w procesie zarzadzania ryzykiem podmiotów gospodarczych. Rzeszów: Oficyna Wydawnicza Politechniki Rzeszowskiej, ISBN 978-83-7934-139-9.

Bera, A. (2005). Ocena i wykorzystanie ubezpieczeń przez mikroprzedsiębiorstwa. W: A. Bielawska, red., Uwarunkowania rynkowe rozwoju mikro i matych przedsiębiorstw, Szczecin: Wydawnictwo Uniwersytetu Szczecińskiego.

Borda, M., Kwiecień, I. (2007), Analiza wykorzystania ubezpieczeń gospodarczych w zarządzaniu ryzykiem przedsiębiorstw. Wiadomości Ubezpieczeniowe, $\mathrm{nr}$ 3/4. 
Dankiewicz, R., Ostrowska-Dankiewicz, A. (2014). Ubezpieczenia w procesie zarządzania ryzykiem na przykładzie przedsiębiorstw zrzeszonych w Podkarpackim Klubie Biznesu W: M. Kaczała, J. Lisowski, M. Osak, red., Aktualne problemy wybranych ubezpieczeń majątkowych, Poznań: Wydawnictwo UE w Poznaniu.

Ernst \& Yung (2009). The Future of Risk. Protecting and Enabling Performance.

FERMA (2003). Standard zarzadzania ryzykiem.

Gajda, D. (2014). Rola ubezpieczeń majątkowych w zarządzaniu ryzykiem małych i średnich przedsiębiorstw. Zeszyty Naukowe Uniwersytetu Szczecińskiego, 804.

Gaschi-Uciecha, A. (2016). Badanie stopnia wdrożenia zarzadzania ryzykiem w małych i średnich przedsiębiorstwach - wyniki badań. Zeszyty Naukowe Politechniki Ślaskiej”, seria Organizacja i Zarzadzanie, 89.

Hadyniak, B. (2010). Przewidywalność, wartość i ryzyko. W: J. Handschke, J. Monkiewicz, red., Ubezpieczenia. Podręcznik akademicki. Warszawa: Poltext.

Hida, E. ed. (2015). Global risk management survey, ninth edition. Operating in the new normal: Increased regulation and heightened expectations, Deloitte University Press, http://dupress.com/articles/global-risk-management-survey-financial-services/ [dostęp: 1.10.2020].

Jajuga, K. red. (2007). Zarządzanie ryzykiem, Warszawa: Wydawnistwo Naukowe PWN.

Jedynak, P. (2009). Podaż usług ubezpieczeniowych a ciągłość działalności małych i średnich przedsiębiorstw. Wiadomości Ubezpieczeniowe, 4.

Kasiewicz, S. red. (2011). Zarządzanie zintegrowanym ryzykiem przedsiębiorstwa $w$ Polsce. Kierunki i narzędzia. Warszawa: Oficyna Wolters Kluwer Business.

Kasiewicz, S., Kurkliński, L., Świerżewski, Ł. (2011). Pasywne podejście do zarządzania ryzykiem. https://www.hbrp.pl/b/pasywne-podejscie-do-zarzadzania-ryzykiem/1D7wMooL3 [dostęp: $1.10 .2020]$

Kaszuba-Perz, A., Perz, P. (2010). Rola zarządzania ryzykiem w przedsiębiorstwie w obliczu wzrostu zewnętrznych czynników ryzyka. e-Finanse, 6, 2.

Kowalewski, E. (1997). Wprowadzenie do teorii interesu ubezpieczeniowego. W: A. Wąsiewicz, red., Ubezpieczenia w gospodarce rynkowej 3. Bydgoszcz: Oficyna Wydawnicza Branta.

Lisowski, J. (2021). Wpływ pandemii związanej z COVID-19 na rynek ubezpieczeniowy w Polsce. W: M. Zaleska, red., Wplyw pandemii COVID-19 na finanse. Polska perspektywa. Warszawa: Difin.

Mikulska, A. (2010). Zarządzanie ryzykiem jako czynnik sprzyjający wzrostowi MSP. Współczesne Zarządzanie, 4.

Monkiewicz, J., Gąsiorkiewicz, L., red. (2010), Zarządzanie ryzykiem działalności organizacji. Warszawa: Wydawnictwo C.H.Beck.

Mowbray, A.H., Blanchard, R.H. (1961). Insurance It is Theory and Practice in the United State, New York.

Prime, H., Wade, M., Browne, D.T. (2020). Risk and resilience in family well-being during the COVID-19 pandemic. American Psychologist, 75, 5, pp. 631-643, DOI: 10.1037/amp0000660.

Przetacznik, S. (2017). Charakterystyka systemów zarządzania ryzykiem stosowanych przez największe spółki giełdowe w Polsce. Zeszyty Naukowe Politechniki Częstochowskiej, Zarządzanie, 28, t. 2, s. 37-49, http://www.zim.pcz.pl/znwz [dostęp: 1.10.2020].

Raport AON Polska (2019). Zarządzanie ryzykiem i ubezpieczeniami w firmach w Polsce, VI edycja, https://aoncomauthoring.blob.core.windows.net/aoncom2017media/aon.com/media/poland/publikacje/raport\%202019-2020/raport-grms-polska-2019-20.pdf?utm_source=Aoncom [dostęp: 1.10.2020].

Sobolewki, H., Marcinkowski, B. (2017). Zarządzanie ryzykiem w praktyce gospodarczej. Studia i Prace WNEiZ US, 50/3, DOI: 10.18276/sip.2017.50/3-12. 
Solarz, J.K., Waliszewski, K. (2020). Całościowe zarzadzanie ryzykiem systemowym. Pandemia COVID-19, Kraków-Legionowo: Wydawnictwo Edu-Libri.

Strupczewski, G., Thlon, M. (2014). Wykorzystanie techniki zatrzymania ryzyka przez średnie i duże przedsiębiorstwa w Polsce w świetle badań ankietowych. Wiadomości Ubezpieczeniowe, 3 .

Swiss Re (2011). Product Innovation in Non-Life Insurance Markets. Where little "I" meets big "I". Sigma, 4.

Szewczuk, A. (2012). Zintegrowane zarządzanie ryzykiem w małych i średnich przedsiębiorstwach - próba oceny. Zeszyty Naukowe Uniwersytetu Szczecińskiego, 735, Problemy Zarzadzania, Finansów i Marketingu, 27.

Taleb, N.N. (2007). Czarny labędź: Wpływ wysoce nieprawdopodobny, New York.

Vaughan, E. (1997). Risk Management, Nowy Jork.

Vaughan, E.J., Vaughan, T.M. (2014). Fundamentals of Risk and Insurance, 11 th ed., Hoboken: Wiley.

Verbano, Ch., Venturini, K. (2013). Managing Risks in SMEs: A Literature Review and Research Agenda. Journal of Technology Management \& Innovation, 8(3).

Wadé, M. (2014). Emerging risks and insurability in a complex environment, Sopot: PIU.

Wierzbicka, E. (2014). Znaczenie ubezpieczeń dla przedsiębiorstw sektora MŚP. Zeszyty Naukowe Wyższej Szkoły HUMANITAS. Zarzadzanie, 1.

Wierzbicka, E. (2017). Rola ubezpieczeń w zarządzaniu ryzykiem przedsiębiorstwa. Zeszyty Naukowe Wyższej Szkoły Humanitas. Zarzadzanie, 4.

Williams, C.A. Jr., Smith, M.L., Young, P.C. (2002). Zarzadzanie ryzykiem a ubezpieczenia, Warszawa: PWN.

Wróblewski, R. (2011). Zarządzanie ryzykiem w przedsiębiorstwie. Zeszyty Naukowe Uniwersytetu Przyrodniczo-Humanistycznego w Siedlcach, 90, Seria: Administracja i Zarządzanie.

Zdunek, M. (2017). Co drugie przedsiębiorstwo nie ma strategii zarządzania ryzykiem, https://www.dnvgl.pl/news/co-drugie-przedsiebiorstwo-nie-ma-strategii-zarzadzania-ryzykiem-85861 [dostęp: 1.10.2020].

\section{ROLA UBEZPIECZEŃ W KONCEPCJACH ZARZĄDZANIA RYZYKIEM WSPÓŁCZESNYCH PRZEDSIĘBIORSTW}

\section{Streszczenie}

Cel artykułu/hipoteza: Koncepcje zarządzania ryzykiem w przedsiębiorstwie ewoluują w czasie pod wpływem gwałtownych zmian, zachodzących zarówno w otoczeniu zewnętrznym, jak i wewnętrznym. Tradycyjne podejście do zarządzania ryzykiem w przedsiębiorstwie ustępuje miejsca filozofii holistycznego zarządzania ryzykiem. Celem opracowania jest analiza tych dwóch koncepcji pod kątem ustalenia aktualnej roli i praktycznego znaczenia metody ubezpieczeniowej. W opracowaniu zweryfikowano hipotezę badawczą w brzmieniu: Pomimo zmieniających się teoretycznych koncepcji zarządzania ryzykiem, a także relatywnego wzrostu znaczenia ryzyka nie nadającego się do ubezpieczenia, w praktyce biznesowej ubezpieczenia nadal zajmują ważne miejsce zwłaszcza w procesie zarządzania ryzykiem dużych i średnich przedsiębiorstw.

Metodyka: Opracowanie ma charakter teoretyczno-analityczny. Obok przeglądu dostępnej literatury krajowej i zagranicznej, przeanalizowano również wyniki badań empirycznych oraz wybrane raporty instytucji doradczych i konsultingowych, w tym najnowszy raport AON Polska 2019 na temat zarządzania ryzykiem w przedsiębiorstwach. 
Wyniki: W większości krajowych przedsiębiorstw realizowany jest silosowy model zarządzania ryzykiem, a ubezpieczenie jako metoda finansowania skutków urzeczywistnienia się ryzyka wciąż nie traci na znaczeniu. Chociaż względne znaczenie ubezpieczeń maleje z powodu wzrostu znaczenia ryzyka nie nadającego się do ubezpieczenia jak np. ryzyko niestabilności ekonomicznej i geopolitycznej, spowolnienia gospodarczego, wzrastającej konkurencji, czy braku profesjonalnych kadr, to jednak ubezpieczenia nie utraciły kluczowej roli w praktyce, zwłaszcza dużych i średnich przedsiębiorstw.

Słowa kluczowe: zarządzanie ryzykiem, ubezpieczenie, przedsiębiorstwo. 